\title{
RELATIONSHIP BETWEEN TRANSFORMATION AND INSTITUTIONAL CULTURE
}

\author{
L. M. Luvalo \\ Department of Educational Foundations \\ University of South Africa \\ Pretoria, South Africa \\ e-mail: luvallm@unisa.ac.za
}

\section{ABSTRACT}

Transformation of higher education (HE) has again became much discussed issue in the higher in South Africa. Government policy has suggested a system of higher education relevant to the new South Africa.

Since 1994 democratic elections not enough transformation took place in South Africa. This was affirmed by violent student protests two years ago at universities sparked by fees' hikes. In South Africa, institutional transformation and institutional culture have been approached as different phenomena, and recently it was demonstrated that the one cannot exist without the other. The turmoil at South African HE institutions in 2015 and early 2016 highlighted the issues of institutional transformation and institutional culture. The student protests were linked to lack of transformation and an institutional culture that alienates black students. This article explores the concepts of transformation and institutional culture, in the context of HE institutions. I conclude that these concepts are intertwined, therefore we cannot have a completely transformed HE in South Africa until the institutional culture also changes.

Keywords: higher education, institutional culture, reforms, transformation

\section{INTRODUCTION}

What is the relationship between transformation and institutional culture in higher education (HE)? An answer to this question should not be taken lightly because the interrelatedness between these two concepts may be overlooked. In the case of South Africa, transformation and institutional culture in HE are sometimes addressed as separate. For example, much has been written about institutional culture at various HE institutions in South Africa (Bunting and Cloete 2004; Thaver 2006; Higgins 2007; Jacobs 2012; Tabensky and Mathews 2015; Suransky and Van der Merwe 2016) but the interconnectedness between transformation and institutional culture is somehow mixed up. In some cases, this oversight is because of multifaceted challenges ranging from policymaking, pockets of resistance to transformation at some universities and a legacy of racially divided higher education (Reddy 2004).

Institutional culture is, according to Kuhn and Whitt $(1988,39)$ "the collective, mutually 
supporting patterns of norms, values, practices, beliefs and assumptions that guide the behaviour of individuals and groups in an institution of higher learning and provide a frame of reference within which to interpret the meaning of events and actions on and off campus". This definition is very important for the transformation process because it involves important components of what needs to be transformed.

According to Council on Higher Education (CHE 2007), Higgins (2007) and Vice (2015), institutional culture in South Africa is seen through the viewpoint of whiteness study. In this viewpoint, it is contended that institutional culture is above all, experienced by dark staff and understudies as a mind-boggling whiteness of scholarly culture. Whiteness alludes to the group social and emotional components that together establish the implicit strength in advanced education of European and Anglo Saxon qualities and demeanours, as these are recreated and reflected in South Africa.

The whiteness can be experienced as distancing and weakening as in of not being completely perceived by the establishment one is at and consequently making it difficult to feel at home at an institution of HE. Sehoole (2016) argues that not feeling at home by both black academics and students is also exacerbated by the curriculum that leads to the continuation of the Anglo Saxon values and attitudes at some of the historically white institutions.

The recent students protest \#FeesMustFall at institutions of HE towards the end of 2015 and beginning of 2016 highlighted the issues of institutional transformation and institutional culture. Thus, until South Africa addresses these two issues simultaneously, it is clear that the HE system will continue to be in turmoil in the country.

A background to this issue is that the dawn of democracy in South Africa after 1994 brought not only social, political and economic changes but changes to HE, which were characterised by segregation and inequality. In 1996, the National Commission on Higher Education (NHCE) submitted its answer to the late President Mandela, in which they contended for the production of a solitary composed arrangement of HE. Since then, institutions have been stood up to with surprising and expansive requests and difficulties. The remaining challenge is the approach to the link between transformation and institutional culture, and the failure to recognise that one cannot take place without the other.

In 2002, the South African Ministry of Education discharged its proposition, which were endorsed by the cabinet, for the change and rebuilding of the HE framework. Eliminating the contrasts between the previously disadvantaged universities and historically white universities was a focal inspiration driving the South African government's restructuring plan for HE. The rebuilding and solidification of the institutional scene was a key component in the more extensive procedure for accomplishing the more extensive objectives and targets in HE. The 
targets were to guarantee an even-handed, manageable and beneficial HE framework that will be of high calibre and contribute successfully to the HE, abilities, learning and research needs of the nation, and which is consistent with non-misogynist, non-racial and vote based qualities revered in the constitution (Ministry of Education 2002).

The article seeks to conceptualise transformation and institutional culture and indicate the inextricable relationship between the two phenomena and the importance of this relationship for progress in terms of change in the South African HE system. This article has three sections. Section one gives a background on transformation of HE in South Africa. The second outlines the theoretical underpinnings of transformation and institutional culture. The third section concludes and suggests future approaches to change strategies in HE, applying both transformation and institutional culture. The two concepts "institutional culture" and "transformation" are discussed extensively in the following section.

\section{REVIEW OF THE CONCEPTS}

This section addresses the concepts of transformation and institutional culture at institutions of HE in South Africa.

\section{Transformation}

Du Preez, Simmonds and Verhoef (2016) state that transformation is a complex, open-ended concept, which was used in the 1950s meaning to undergo change. To change is accordingly to cause or experience an adjustment in structure, nature and appearance. Some writing on change in HE centers around hierarchical change and most writing spotlights on the procedure (Sporn 1996; Bunting and Cloete 2004; Kezar and Eckel 2002; Manning 2013).

Transformation of an institution does not occur in isolation; it is usually brought about by changes taking place within and outside of the institution. For example, in an international context, a changing educational environment like technology, new financial environments, new markets and competition, changing student's demographics and globalisation are all transformation issues (Kezar and Eckel 2002). In South Africa, similar issues, especially after the 1994 democratic elections, have led to institutional transformation. However, according to Du Preez et al. $(2016,2)$ the focus is on the following discourses. Structural discourses, which are concerned with transformation to a democratic society, the issue of equality and the efficiency of the HE system is primary in this view of transformation, driven by the Education White Paper of 1997 (DoE 1997). The second discourse is on ideology and a deeper understanding of transformation, which developed because of the 2008 Report of the Ministerial Committee on Transformation, Social Cohesion and the Elimination of 
Discrimination in Public Higher Education (MCTHE) institutions. The third discourse is on aspects such as curriculum change, institutional management structures, teaching and learning.

Change associated with the transformation of an institution is associated with implementing a unique cluster of strategies and activities, the most important aspect being transformation of institutional culture. Spencer (1991), Kuhn and Whitt (1988), Schien (1992) as well as Tierney (1998) alludes that transforming an institution requires a change of all culturally dominant elements like, shared assumption, values, beliefs, ideologies and meanings that people have about their organisation. Vice (2015) also defines institutional transformation, strongly linking it to institutional culture, especially in HE institutions, as a direct removal of a distinct hierarchy and alienation, making everyone, whether they are pursuing academic support or a management task, feel equally welcome and valued in a project whose importance is evident to everyone in some way.

Defining transformation in South African HE institutions, Chetty and Merret $(2014,27)$ see it as "wider access for black African students and acceptable pass rate, despite the collapsing state of high school system". There were also complaints about curriculum, which was said to be too Eurocentric and this contradicted with former President Mbeki's vision of African Renaissance. Transformation meant diversification of the university and institutional culture management. Chetty and Merrett (2014) laments that procedures that were tried and tested were set aside in terms of staff equities, resulting in instances were experienced people were overlooked.

Brink $(2007,3)$ explains the challenge for some institutions in trying to understand what exactly transforming an institution means. He argues that transformation meant nothing more or less than "affirmative action", the blunt end of which translated into more "more black students and staff". To others transformation means "Africanisation", which typically had to do with a radical redesign of the curriculum. Brink (2007) later realised that transformation at Stellenbosch would have to be based on a change of consciousness, as he was shocked with the lack of transformation he observed when he returned to the university in 2005 after he had left. This briefly indicates how various interpretations of what is to transform can lead to no transformation at all. In Brink's words, the institution can learn something on transformation and HE would not experience protests related to lack of transformation.

Transformation is always contested due to its nature and sometimes misguided attitudes towards it. It is however important to understand transformation at HE institutions as involving strategic planning, bureaucratic and scientific management, and organisational development. Kezar and Eckel $(2002,17)$ suggest five primary core strategies that transformation of institutions should be based on, "namely senior administrative support, collaborative 
leadership, flexible vision, staff development and visible action". These strategies always play a role in supporting and contributing to the implementation of core strategies. It is therefore important to understand that transforming an institution occurs overtime, there must be tangible strategies to bring about a real transformation.

Transformation of HE is viewed by Harvey and Knight (1996) as a process driven by motivation to expand $\mathrm{HE}$ and increase participation rates, with a vision of the world economy. These authors further argue that if HE is to play an effective role in education for 21 st century, it must focus on the transformative process. This proposes that HE should be changed so that it produces transformative agents; fundamentally intelligent students ready to adapt to quickly changing world. In South Africa some HE institutions after 23 years of democracy seem not to indicate the production of transformative agents. Harvey and Knight $(1996,10)$ introduce the idea of "critical transformation", explaining transformation as a process of changing one form into another. Educationally, this alluded to change in then information and capacities of students in creating skills, however it likewise alludes to the way comprehending.

Kogan and Hanney $(2000,41)$ refers to another type of transformation, which is called "critical transformation, which originates from critical thinking theory". These creators approach basic change at HE institutions from the perspective on student's learning. This agrees with the past affirmations about parts of change. Basic change is characterized as observing quality as far as the degree to which the training framework changes the applied capacity and mindfulness of the student. Basic change additionally includes tending to an issue in detail while all the while setting it inside a more extensive setting. This prompts transformative getting tangible. Transformative learning includes a procedure of deconstruction and recreation, which is one of the issues students referenced about the educational modules at universities. Deconstruction gets underneath surface appearances; be they customary models of working, underestimated frames of mind, inserted qualities, winning legends, philosophy or verifiable truths. In the South African HE context, transformative learning would mean decolonisation of the curriculum (Murris 2016).

At a Mail and Guardian Critical Thinking forum at University of South Africa (UNISA) Tufvesson (2016), characterized transformation as a cognizant procedure of logically explicit multi-zones that require change with the goal for there to be no likeness the past in the present; the past has regularly been consented to be unsuitable and has constrained the requirement for change in any case. It is subsequently not an all-around relevant procedure; change is a procedure of fixing what has been generally distinguished at a particular point in time and spot as being treacherous, inadmissible inexcusable, unfortunate and inconvenient. Tufvesson further contends that change requires relevantly explicit intercession. This is a relevant 
argument for transformation in a South African context given the fact that higher education is still experiencing the challenges after 23 years of democracy.

It is evident that transformation is viewed differently as Du Preez $(2016,2)$ confirms that transformation can be "loosely defined as inherently complex". However, a common trend that emanates from the literature is that, transformation must mean a move from a certain state to another. The following section focuses on institutional culture, how it is defined and later will discuss the relationship between the two concepts.

\section{Institutional culture}

CHE $(2007,4)$ defines institutional culture as, "the present predominant feeling of the term in South Africa, comprehends the institutional culture of HE through the perspective of white scrutinize". In this point of view, it is contended that institutional culture is over all felt by staff and students of colour as overpowering whiteness of scholastic culture. Whiteness here alludes to the group social and emotional components that together comprise the implicit predominance in HE of Western European and Anglo Saxon qualities, frames of mind, as these are imitated and reflected in South Africa. This whiteness can be experienced as distancing and impairing in the sense of not being completely accommodated by the institution one is at and in this manner the inconceivability of feeling comfortable within the institution. An example of this can be found at institutions like the universities of Cape Town, Rhodes and Witwatersrand, where most black students complained about the alienating culture and curriculum of the institutions (Tabensky and Mathews 2015).

Institutions of HE can achieve a better understanding of institutional culture by exploring the forms of self-concept. As per Toma, Dubrow and Hartley (2005), the core of institutional culture is in the measures, characteristics and feelings of an institution. These models, characteristics and feelings are made indisputable through social structures, which join the pictures, language, records and practices of the establishment. Jacobs (2012) also observes that forms of culture are one of a kind to each university. Institutional culture further has emotional measurements (shared suppositions, values, suggestions, understandings, etc.) and progressively target perspectives (physical antiquities, authoritative stories, legends and courageous women, customs and services), the previous being less clear than the images, language accounts and practices required for passing on them (Duncan 1989). Sackman (1992) depicts these measurements along three lines as alcoholic (mind-sets, feeling and responding), variable (articulation of culture) and intellectual (convictions, qualities and standards). Kuhn and Whitt (1988) term them item and procedure. 


\section{Symbols}

Symbols speak to what the association intends to members and help them comprehend their encounters in the association. Symbols have a number of functions. They associate individuals with institutions and give a touchstone to individuals in the all-inclusive university network, and they are a solid portrayal of what the foundation is about (Alvesson 2012).

Another imperative normal for symbols is that they appear as objects. Objects progress toward becoming permeated with implications due to their relationship with specific university. A logo, similar to a university seal is such an item as-image and frequently contains data, for example, the establishing date and the aphorism of the college, (ASHE 2005, 39-54). An institution's physical setting (outside condition) is itself a powerful image, proposing a glad convention. A few foundations have signature structures. People may likewise fill in as imperative images. Images inspire the foundation as both idea and solid element, and urge constituents to relate to organizations. Additionally, images make progressively unmistakable what separates the picture of a university from another, what is more, they underscore the drivers of institutional recognizable proof (ASHE 2005).

Images speak to what the association intends to members and help them comprehend their encounters in the association. Images have a few capacities. They interface individuals with institutions and give a touchstone to individuals in the all-inclusive college network, and they are a solid portrayal of what the establishment is about (Alvesson 2012).

\section{Language}

Language is an arrangement of sounds, signs and motions individuals in any association use to pass on implications to each other. The framework enables a specific grounds network to talk a similar language, accordingly fortifying the obligations of affiliation, and it gives a way to express the picture of the institution (Jiang 2000). Language goes up against a large number of structures. Language (specific language specific to a particular gathering) and slang are different methods for passing on a feeling of being part of a place (Toma et al. 2005, 65). Hammond (1994) observes the association among slang and culture, and battles that slang has been used to portray basically every component of grounds life. As student-culture routinely stays in opposition to the workforce, slang serves the imperative limit of isolating students from power. Language and slang may at first be difficult to reach to newcomers and pariahs, however once they are found out, it shows a longing to have a place with a specific association. Axioms and mottos are ordinarily utilized at HE institutions. Sayings are short articulations of people knowledge, while mottos are purposeful proclamations. Adages and trademarks regularly identify with the philosophy (arrangement of convictions) basic to grounds (Parekh 2008). The 
idea of philosophy underscores that, albeit social structures like language are regular crosswise over institutions, the subtleties related with these structures vary from campus to campus due to various social settings. What is regular is the utilization of structures to make institutions progressively available while speaking to them in increasingly unmistakable routes (than the apparent inflexible expert language of the staff), in this manner empowering institutional identity.

\section{Narratives}

Narratives use language and images as fantasies, adventures, legends and stories. Myths or fantasies are emotional, ambiguous and unchallenged stories of envisioned occasions, used to clarify the beginnings of change of something saw as genuine or hallowed. Sagas resemble fantasies, however depend on records of memorable occasions generally surrounded in sentimental terms (Toma et al. 2005). Institutional sagas encourage dedication and are profoundly established ever. Regardless of adventures value in formalizing a feeling of solidarity, Tierney (1988) cannot help contradicting the view that sagas are hierarchical substances that everybody can comprehend and translate, and takes note of that adventures do not reflect worry with social equity. Stories pass on critical social implications and are markers of shared qualities and understandings about how things are done, and the results of consistence or abnormality.

\section{Practices}

Practices allude to exercises, for example, customs, services and ceremonies proposed to pass on critical social messages (Parekh 2008). Rituals are arranged sets of exercises, loaded with dramatization, and did to serve a crowd of people. Services are a few ceremonies associated in a solitary event. Customs symbolize hidden social qualities, in this way strengthening customary social ties. The yearly conference functions are instances of customs that hold together over a significant time span institutional practices. Customs are vital in institutional life since they keep belief system alive and support a feeling of having a place. Besides, their impact on a substantial gathering of members fortifies the qualities that networks hold or which they hope for. Likewise, ceremonies can be vital socialisers of prevailing social qualities, regardless of whether for the establishment or the general public; they give significance and reason to members.

Suransky and Van der Merwe $(2016,579)$ have characterized institutional culture as "deeply embedded patters of organisational behaviour and the shared values assumptions, beliefs or ideologies that members have about their organisations or its work or its work". This 
definition incorporates the examples of institutional culture likewise shared by Kuhn and Whitt (1988). Qualities, frames of mind and customs are foundations of institutional culture that need to change at some HE establishments.

\section{CURRENT ASPECTS OF TRANSFORMATION AND INSTITUTIONAL CULTURE IN SOUTH AFRICA}

The Soudien Report (2008) identifies transformation and gives meaning to three important aspects: policy and compliance, epistemological change and institutional culture. Firstly, on policy and compliance, the report argued that some HE institutions were comfortable in merely complying with laws on transformation as indicated by their transformation indicators. Secondly, the report called for curriculum transformation, which can only happen when HE institutions interrogate the sources of knowledge and how that knowledge is passed to the students. Thirdly, the report commented on institutional culture at HE institutions, arguing that most white universities have an alienating institutional culture.

Using methodologies of transformation, the institutional culture can be changed by Africanisation of the institution, indigenising knowledge, diversifying and decolonising $\mathrm{HE}$ institutions. An ideal transformed institution will be reflected in what students learn with an emphasis on African philosophies and knowledge that is pertinent to the student's environment. Therefore, it becomes clear that the link between transformation and institutional culture is based on the methodologies of transformation; therefore, one dimension cannot be changed without the other.

Governance and leadership are important in the interrelation of institutional culture and transformation. A culture of an institution emanates from these two because they determine the decision-making methods of an institution. The issue of funding HE in South Africa highlighted by the \#FeesMustFall student movement. This has become important because there can be no transformation of HE if there is no proper model of funding HE. In South Africa, institutions of HE have not been equally funded for years. The historically white universities manage to have more resources due to the advantage of the ability to source funding from research output, student fees and alumni. On the other hand, black institutions mostly depend on the government because student fees contribution is poor.

Transformation and institutional change are also about issues like staffing equity, development and work experience at institutions of HE. For example, having an equitable number of both black and white academics not only transforms an institution but also leads to change in its institutional culture. It is also important for the academics to perceive the culture of the institution as accommodative towards them. As indicated earlier, language is an 
important aspect of institutional culture; therefore, student learning in a language that they understand will facilitate their progress at university. Figure 1 indicates the picture in terms of staffing at institutions of HE in South Africa from 2010 to 2015.



Figure 1: Headcount of overall university staff members by race from 2010 to 2015 (CHE 2015)

Figure 2 indicates progress or lack of transformation in terms of senior management positions in South African universities. In addition, Figure 2 gives racial depiction on senior management positions from 2010 to 2015. Management plays an important role in creating a certain environment for institutional culture and transformation. Figure 2 indicates disparities in terms of racial inequality when it comes to management positions at universities in South Africa between 2010 and 2015. Since 2010 white academics still occupy most of management positions and there is slow growth in terms of appointing black, coloured and Indian academics into these positions.

Paul and Berry (2013) indicate the importance of leadership in influencing the culture of the institution. Strong leadership listens to people and address their challenges pertaining to the culture of the institution. The question that arises from Figure 2 is that if the number of black staff in senior management positions until 2015 is still low, what are the implications on transformation at HE institutions in South Africa? It can be concluded that the process of transformation will always be slow and perpetuate staff inequalities that existed at some institutions prior the democratic government of 1994. 


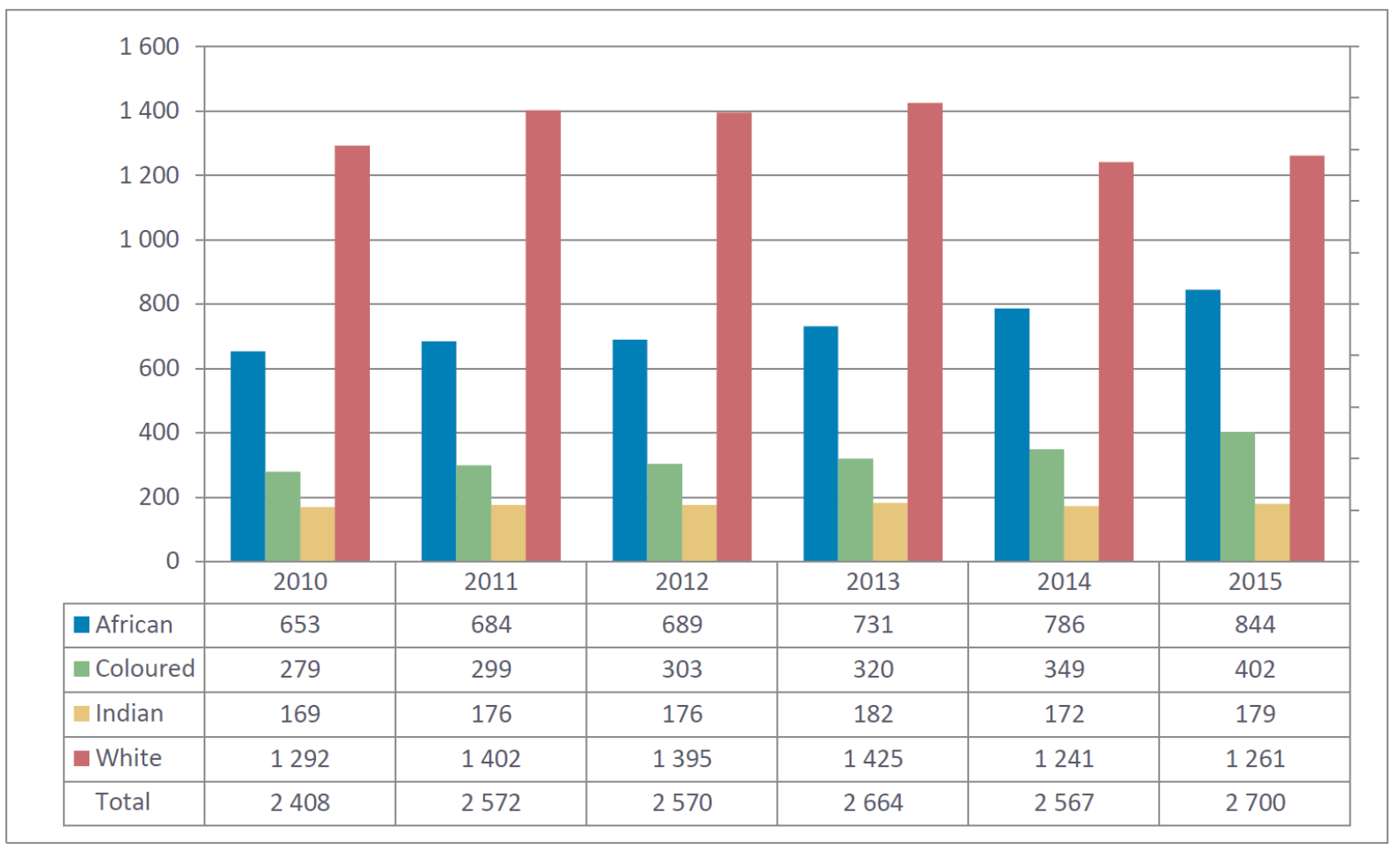

Figure 2: Headcount of senior management by race from 2010 to 2015 (CHE 2015)

The South African Human Rights Commission (SAHRC) Report Transformation at Public Universities in South Africa (SAHRC Report 2016) reiterated the slow pace of transformation at some universities. This research was conducted after 20 years of democracy in South Africa. Among other key questions that were addressed during the hearings were the university culture and transformation policies at universities. SAHRC observed that there were differences in terms of policies and structures at various institutions (SAHRC Report 2016).

A portion of these distinctions incorporate that while different universities tended to the issue of change through creating change contracts, a few universities decided not to incorporate change strategies in their planning. Further, while a few universities have created independent and point by point institutional change designs, others have consolidated these plans into the general institutional vital arrangement. In addition, a portion of the created change sanctions fill in as an insignificant articulation of change targets. These contracts do not unmistakably show targets, timetables, monitoring instruments and capable structures, while others incorporate imperative topics that ought to be the focal point of change (SAHRC Report 2016).

On the issue of institutional culture at institutions of higher learning, staff, understudies and workers associations like the National Education and Health Allied Workers Union (Nehawu) made entries. Nehawu expressed that students from the underprivileged community, who manage get to HE end up in a domain where the requirements and estimations of their own networks are disregarded. To exacerbate their feeling of estrangement, Nehawu presented that 
students from the underprivileged black communities who enlisted at previously white universities, wind up feeling unwelcome at those institutions. Nehawu further presented that a disguised type of prejudice is rising in post-politically-sanctioned racial segregation South Africa. This type of prejudice frequently dodges racial phrasing, while at the same time remaining positively imbedded in the everyday activities of numerous organizations. As indicated by Nehawu, this type of prejudice drives institutional culture. Alluding to Randall (2006), Nehawu featured that the peril in institutional prejudice is that it is frequently obviously and secretively imbedded in the establishment's way of life, foundational strategies and rehearses and that such societies, arrangements and practices are regularly not racially roused, however are persuaded by reasons, for example, effectiveness, profitability and meritocracy. In such conditions, the most serious risk may lie in that people and additionally institutions of higher education may not know about the embedded types of prejudice (SAHRC Report 2016).

It is evident from this report that after almost 23 years of democracy in South Africa, some of the universities are still lagging behind in terms of transformation and their institutional culture. This has led to the recent campaigns like "Rhodes Must Fall", "Fees Must Fall" and the "Outsourcing Must Fall" protests. The government in trying to remedy the situation set up a Fees Commission of Inquiry, trying to find a better model of funding students at universities. Figure 3 indicates the gender disparities at institutions of HE in South Africa.

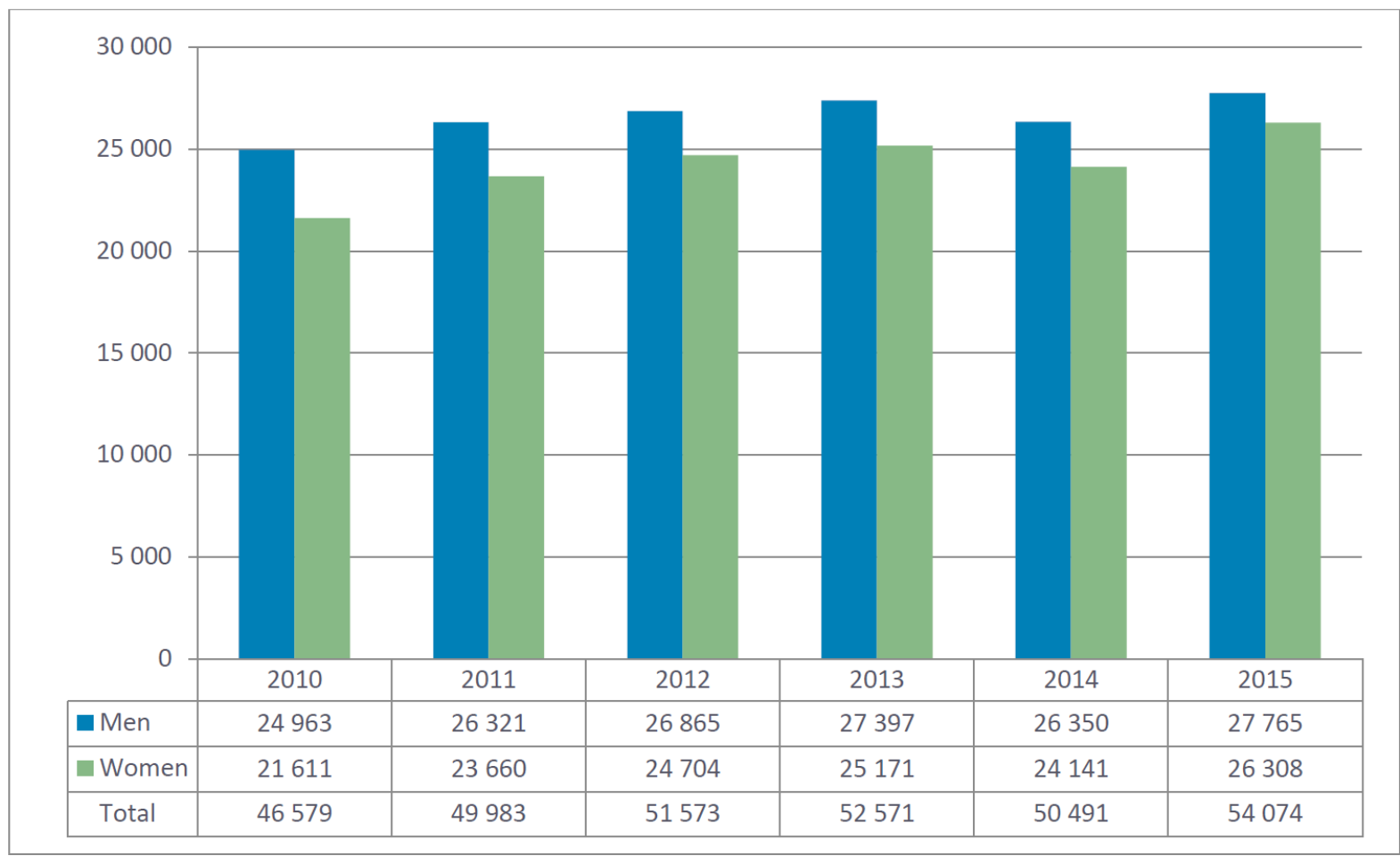

Figure 3: Headcount of academic staff members by gender from 2010 to 2015 (CHE 2015) 
Figure 3 indicates that men still form a larger number of academics compared to women in HE in South Africa. Although there has been a slight increase in terms of the number of women, men still hold positions that are more senior. It questions the equity policies of the institutions and the willingness of the institutions to comply with the country's labour laws, which advocate for equal gender representation in all organisations. From this data, it can be concluded that full transformation has not taken place in terms of gender equity in $\mathrm{HE}$ as pronounced by Education White Paper 3 of 1997 (DoE 1997).

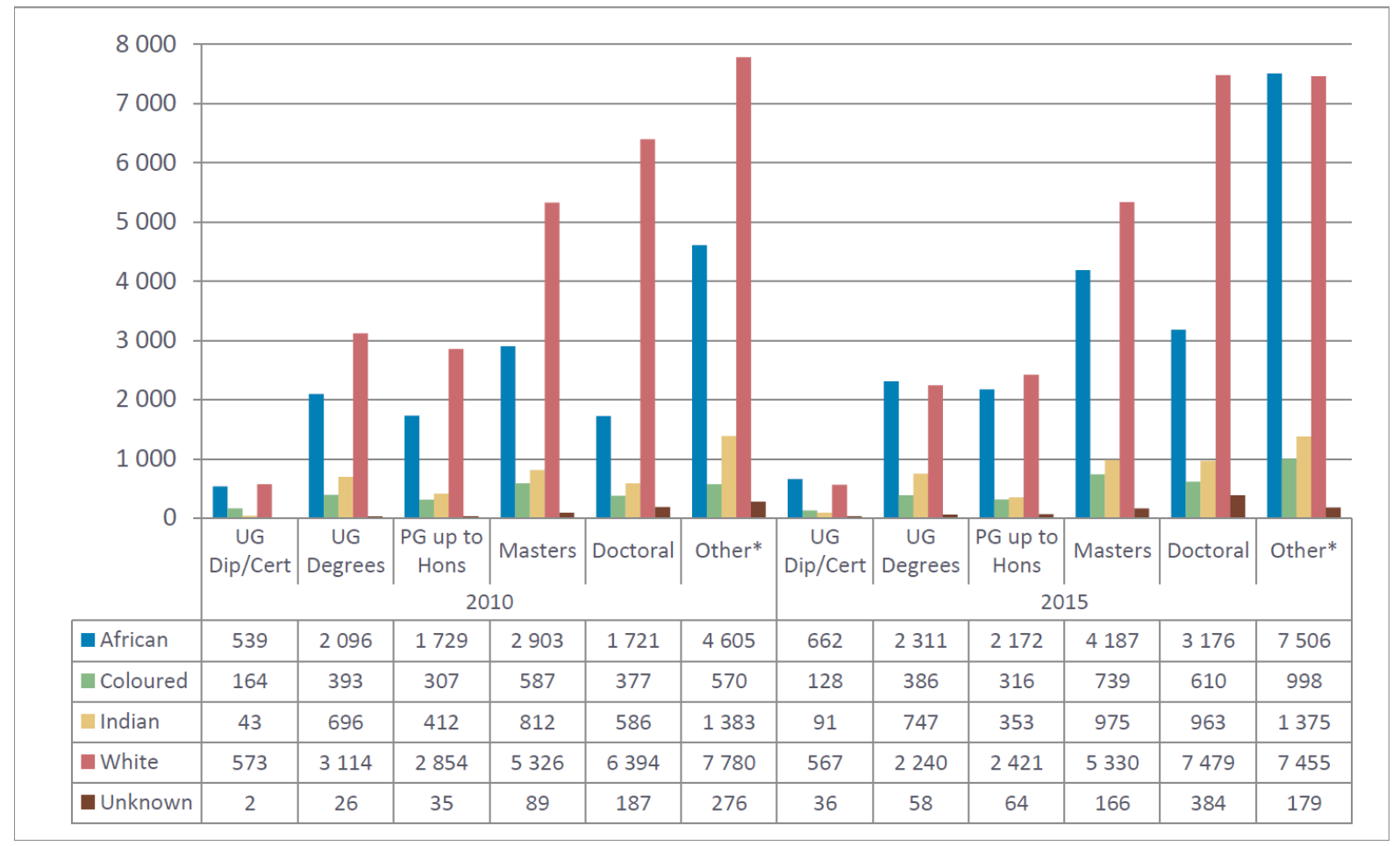

Figure 4: Headcount of academic staff by race and qualification level from 2010 to 2015 (CHE 2015)

Figure 4 indicates transformation in terms of the number of academics at South African universities in terms of race. Qualifications are important in terms of development and influencing management and subsequently institutional culture of an institution. Qualifications also determine who is promoted to a senior level, who influences what must be taught, research outputs and control of production of knowledge.

There is a varying difference between Africans with postgraduate qualifications and their white counterparts. There is still a huge gap in terms of black academics with doctorates as compared to white academics and this has an impact on student output. Qualifications are important for developing and influencing management and subsequently institutional culture. At university, this is reflected by promotion to senior level, research outputs and the control of the production of knowledge. Transformation in these areas is seemingly very slow although 
there are interventions by other institutions to increase the number of black academics with doctorates. The implication of the inequities reflected in figure 4 is that a certain dominant institutional culture remains influential as indicated in the 2016 SAHRC Report on Transformation at Public Universities in South Africa.

\section{CONCLUSION}

There is an assumption in South Africa that transformation of institutions of HE can take place without changing institutional culture. However, this article argues that there is a need to change this perception because the two concepts are intertwined. This point was highlighted by exploring both the concepts of institutional culture and transformation in literature. The meaning of institutional culture like shared values, beliefs, language and symbols indicates a particular culture at the institution. For substantial transformation at any institution, these needs change that appears to not have occurred in some South African HE institutions for the past 20 years. Institutions of HE need to take bold steps on racial representatives in management and knowledge production at universities, as Figure 4 still reflects a skewed picture in this area. The recent student protests at institutions of $\mathrm{HE}$ are a sign that transformation has been ignored for too long. Whether it is an issue of decolonising the curriculum, \#FeesMustFall and \#AfrikaansMustFall, the protests indicate the slow pace or lack of transformation at some universities.

As earlier indicated at the beginning of this article, the suggestion is that glossing over the unwillingness to change institutional culture at some known universities in South Africa is equal to disregarding the very South African Higher Education Act of education that promulgates equal participation in HE for all.

\section{REFERENCES}

Alvesson, M. 2012. Understanding organizational culture. Sage: Los Angeles.

ASHE see Association for the Study of Higher Education.

Association for the Study of Higher Education. 2005. Understanding institutional culture. ASHE Higher Education Report 31(2): 39-54.

Brink, R. M. 2007. A guideline framework for transformation to a LED approach in local government: The Frances Baard district. Doctoral dissertation, University of Stellenbosch, Stellenbosch.

Bunting, I. and N. Cloete. 2004. Developing performance indicators for higher education: A South African case study (Vol. 3). Pretoria: CHET.

CHE see Council on Higher Education.

Chetty, N. and C. Merret. 2014. The struggle for the soul of a South African university: The University of KwaZulu-Natal: South Africa.

Council on Higher Education. 2007. Review of higher education in South Africa. Pretoria: CHE. 
Council on Higher Education. 2015. Vital stats: Public higher education. Pretoria.

DoE see Department of Education.

Duncan, W. J. 1989. Organizational culture: "Getting a fix" on an elusive concept. The Academy of Management Executive 3(3): 229-236.

Du Preez, P., S. Simmonds and A. H. Verhoef. 2016. Rethinking and researching transformation in higher education: A meta-study of South African trends. Transformation in Higher Education 1(1): a2.

Department of Education. 1997. Education White Paper 3: A Programme for the Transformation of Higher Education. Government Gazette No.18207. Pretoria.

Harvey, L. and P. T. Knight. 1996. Transforming higher education. Society for Research into Higher Education: Bristol.

Hammond, C. 1994. Integrating service and academic study: Faculty motivation and satisfaction in Michigan higher education. Michigan Journal of Community Service Learning 1(1): 21-28.

Higgins, J. 2007. Institutional culture as keyword. Review of higher education in South Africa. http://www.che.ac.za/documents/d0001146/8-Review HE SA 2007.pdf (Accessed 9 March 2014).

Jacobs, A. H. 2012. A critical-hermeneutical inquiry of institutional culture in higher education. Unpublished PhD dissertation. Stellenbosch: Stellenbosch University.

Jiang, W. 2000. The relationship between culture and language. ELT Journal 54(4): 328-334.

Kezar, A. and P. D. Eckel. 2002. The effect of institutional culture on change strategies in higher education: Universal principles or culturally responsive concepts? The Journal of Higher Education 73(4): 435-460

Kogan, M. and S. Hanney. 2000. Reforming higher education: Higher education policy series 50. Jessica Kingsley Publishers: London.

Kuhn, G. D. and E. J. Whitt. 1988. The invisible tapestry: Culture in American colleges and universities. ASHE-ERIC Higher Education Report No. 1. Washington

Manning, K. 2013. Organisational theory on higher education. Routledge: New York.

Ministry of Education. 2002. Transformation and restructuring: A new institutional landscape for higher education. Pretoria: Government Printers.

Murris, K. 2016. \#Rhodes must fall: A post humanist orientation to decolonising higher education Institutions. South African Journal of Higher Education 30(3): 274-294.

Parekh, A. 2008. Comprehensive university reality fraught and complicated. www.universityworld news.com (Accessedd 29 May 2017).

Paul, G. W. and D. M. Berry. 2013. The importance of executive leadership in creating a post-merged organisational culture conducive to effective performance management. South African Journal of Human Resource Management 11(1).

Randall, V. R. 2006. The misuses of the LSAT: Discrimination against blacks and other minorities in Law School Admissions. John's L. Rev. 80: 107.

Reddy, T. 2004. Higher education and social transformation: South Africa case study. South African Journal of Higher Education 21(3): 485-502.

Sackman, S. A. 1992. Culture and subcultures: An analysis of organizational knowledge. Administrative Science Quarterly: 140-161.

SAHRC Report. 2016. Transformation at public universities in South Africa. Johannesburg.

Sehoole, C. 2016. Mail \& Guardian Critical Thinking Forum: What does institutional culture change mean for transformation in higher education? 18 November.

Soudien Report. 2008. Report of the Ministerial Committee on Transformation and social cohesion and the elimination of discrimination in public higher education institutions. Pretoria: Ministry of Education, 30 November 2008. 
Sporn, B. 1996. Managing university culture: An analysis of the relationship between institutional culture and management approaches. Higher Education 32(1): 41-61.

Suransky, C. and J. C. van der Merwe. 2016. Transcending apartheid in higher education: Transforming an institutional culture. Race Ethnicity and Education 19(3): 577-597. DOI: 10.1080/13613324.2014.946487.

Tabensky, P. A. and S. Matthews. 2015. Being at home: Race, institutional culture and transformation at South African higher education institutions, ed. P. Tabensky and S. Mathews, 45-71. University of KwaZulu-Natal Press.

Thaver, L. 2006. At home: Institutional culture and higher education: Some methodological considerations. Perspectives in Education 24(1): 15-26.

Tierney, W. G. 1988. Organizational culture in higher education: defining the essentials. The Journal of Higher Education 59(1): 2-21.

Toma, J. D., G. Dubrow and M. Hartley. 2005. The uses of institutional culture: Strengthening identification and building brand equity in higher education. ASHE Higher Education Report 31(2): $1-105$.

Tufvesson, I. 2016. Mail \& Guardian Critical Thinking Forum: What does institutional culture change mean for transformation in higher education? 18 November.

Vice, S. 2015. Feeling at home: An institutional culture of and the idea of a university. In Being at home: Race institutional culture and transformation at South African higher education institutions, ed. P. Tabensky and S. Mathews, 45-71. University of KwaZulu-Natal Press. 